\title{
THE EFFECT OF QUALITY OF SERVICE AND PRICE ON CUSTOMER SATISFACTION ON GRILLED CHICKEN RESTAURANTS OF PAK ATOK BAKOM CIAWI BOGOR
}

\author{
Tanti Setiowati $^{1^{*}}$, Sakti Brata Ismaya ${ }^{2}$ \\ ${ }^{1,2}$ Universitas Respati Indonesia \\ E-mail: ${ }^{1)}$ inaz.tanti@gmail.com
}

\begin{abstract}
The purpose of this study was to determine the effect of service quality and price on customer satisfaction on grilled chicken restaurants of Pak Atok Bakom, Ciawi Bogor. This study is a quantitative approach. The population in this study are consumers who visit the Grilled Chicken Restaurants of Pak Atok Bakom, Ciawi Bogor. Meanwhile, the sample used was based on the Accidental method, which is a technique for determining the sample based on needs only, members who were met by researchers and were willing to become respondents. The type of data used in this study is quantitative data which obtained through an online questionnaire, namely the Google Form. Questionnaires are used to obtain respondent data regarding service quality, price and customer satisfaction with data sources obtained directly from consumers or customers who have been or are now customers of Pak Atok Bakom's Grilled Chicken Restaurant in Ciawi Bogor. Moreover, the data analysis carried out by several test, namely Validity test, Reliability test, and Hypothesis test. The finding reveals that service quality has a significant effect on customer satisfaction and the price has a significant influence on customer satisfaction. Likewise, service quality and price has a significant effect on customer satisfaction, it is proven by path coefficient value of service quality and price on customer satisfaction which are 0,000 and the t-statistic is 5,381, hence the t-statistic is significant because $>1,96$ with $p$ value $<0,00$.
\end{abstract}

Keywords: Service Quality, Price, Customer Satisfaction

\section{INTRODUCTION}

The business sector must be able to maximize its company's performance, notably in the area of culinary food, in order to compete in the market in a healthy manner in this increasingly competitive era. Yet the company must do everything it can to study and understand its consumers' requirements and expectations. As a possible consequence, organizations will be able to construct marketing strategies based on the needs and desires of customers in order to achieve customer satisfaction. As a result, many customers mention their commitment to customer satisfaction in their purchase order information. Customers' levels of satisfaction or dissatisfaction with a product are a part of the whole customer experience. According to what we've observed, customers tend to select and maintain specific values. Customers will be able to use this value to compare the prices of their own items to those of competitors. As long as a company is delivering high-quality products, it should be able to satisfy or even exceed the expectations of its customers in terms of value and satisfaction.

The Grilled Chicken Restaurant of Pak Atok Bakom Ciawi Bogor has attracted quite a lot of attention from its customers or consumers, but along with the rapid development of 
restaurants, the competition between restaurants has become increasingly fierce. One of the competitions faced by Grilled Chicken Restaurant of Pak Atok Bakom Ciawi Bogor is the high competition between fast food industries in the city of Bogor. With increasing competition due to the number of restaurants in the city of Bogor, Pak Atok Bakom Ciawi Bogor Grilled Chicken Restaurant must carry out alternative strategies to attract as many visitors as possible and retain customers. Therefore, Pak Atok Bakom Ciawi Bogor Grilled Chicken Restaurant must maintain its customers from escaping to other competitors' restaurants by increasing customer satisfaction through quality of service such as, completeness of goods, cleanliness of the room, employee friendliness and the adjusted price expected by consumers or customers.

A low price can lead to customer satisfaction, because customers see the product or service as having more value than the price of the product or service in a narrow sense, while in a broad sense, price is the amount of money consumers exchange for their own benefits or use of the product or service.

By taking into account the background in question, this study aims to analyze the effect of service quality and price on customer satisfaction on Grilled Chicken Restaurants of Pak Atok Bakom, Ciawi Bogor.

\section{LITERATURE REVIEW}

\subsection{Marketing}

Marketing generates revenue that is managed by finance people and then utilized by production people to create products or services. Marketing is concerned with the identification and satisfaction of human and social needs. One of the most succinct definitions of marketing is "profitably meeting customer needs" (Kotler \& Keller, 2012).

\subsection{Service Quality}

Service quality is the expected level of excellence and control over the level of excellence to fulfill customer desires. If the service or service received exceeds customer expectations, then the quality of the service is perceived as ideal. On the other hand, if the service or service received is lower than expected, then the quality of the service is perceived as bad (Thungasal, 2019). Service quality is a characteristic of a product or service that depends on its ability to satisfy customer-centred needs. This study measures service quality by using indicators that refer to tangible theories (Akbar, 2020).

Based on the above definition, we can conclude that service quality is a condition related to the overall characteristics of goods and services to meet the needs, desires and expectations of customers in services that aim to satisfy customers. There are several indicators of service quality are as follows:

1. Tangible

Tangible is concrete evidence of a company's ability to present the best for customers. Both from the physical appearance of the building, facilities, supporting technology equipment, to the appearance of employees.

2. Reliability

Reliability is the company's ability to provide services in accordance with consumer expectations related to speed, timeliness, no errors, sympathetic attitude and others. 


\section{JOURNAL OF MANAGEMENT, ACCOUNTING, GENERAL FINANCE AND INTERNATIONAL ECONOMIC ISSUES \\ (MARGINAL) \\ VOLUME 1 ISSUE 2 (2022)}

\section{Responsiveness}

Responsiveness is providing fast or responsive service and accompanied by a clear and easy to understand delivery method.

4. Insurance

Insurance is a guarantee and certainty obtained from the polite attitude of employees, good communication and knowledge, so as to be able to foster a sense of trust in customers.

5. Empathy

Empathy gives genuine and personal attention to customers, this is done to find out consumer desires accurately and specifically.

\subsection{Price}

Price is strongly tied to and closely related to the fundamental value of consumer perception based on the total retail mix factors in the process of generating a picture and interacting with the product or service in question (Ramadani 2020).

The value included in a price is referred to as its price. Prices have an impact on customer satisfaction because each individual's perception of prices differs from that of other consumers. Price is a consumer or customer's perception of the price with the goal of high or cheap and acceptable prices have a big influence with the intention of buying and buying satisfaction (Mutiara et al., 2021).

Furthermore, price is the amount of money needed to get a certain combination of goods and services. According to the above definition, the policy regarding prices is only temporary, meaning that producers must follow price developments in the market and must know the company's position in the overall market situation (Susanti, 2020).

To determine the price it can be determined by the following indicators, which are as follows:

1) Price match with competitors

It is a price offer given to different and competitive producers/sellers with those provided by other manufacturers, on the same type of product.

2) Price Match With Service

3) Price Match with Facilities

In this case price is more often used as an indicator of quality for customers, people more often choose a slightly higher price between two goods because they see a difference in price quality.

4) Price Match with Benefits

In the aspect of pricing, the first time that is done by the producer in accordance with the benefits is what the customer can get from the product purchased.

\subsection{Customer satisfaction}

Customer satisfaction can be defined as a condition in which the needs, wants and expectations of customers can be met through the products consumed (Ramadan, 2020). Satisfaction can be defined as an attempt to complete or make something appropriate. Customer satisfaction is defined as a person's contentment or unhappiness with the results of a comparison between the performance or quality of a product received and their expectations. Consumers will be unsatisfied if a product's performance falls short of expectations. The consumer will be satisfied if the product's performance meets their 
expectations. If the product's performance meets or surpasses expectations, the customer will be incredibly satisfied (Pratama, 2016).

Customer satisfaction is determined by the product's perceived performance in relation to purchase expectations. The customer feels dissatisfied if the product fails to satisfy expectations. Consumer satisfaction is defined as a reaction to customer behavior measured by comparing performance or perceived results to expectations. If the perceived results fall short of expectations, the customer will be disappointed, unhappy, or even unsatisfied; on the other hand, if the performance meets expectations, the customer will be satisfied; and if the performance exceeds expectations, the client will be extremely satisfied (Praja, 2018).

A customer is someone who comes to the same area on a regular basis and repeatedly to satisfy his or her need by purchasing a product or receiving a service and paying for the product or service received (Kristianti \& Rivai, 2018).

Besides that, there are factors that affect the level of customer satisfaction according to Kotler \& Keller (2012), namely :

1) Overall Satisfaction (Feeling satisfied with the customer on the overall product or service)

2) Confirmation Expectation (Conformity with customer expectations)

3) Comparison to Ideal (Exceeded customer expectations)

\section{RESEARCH METHOD}

The research approach used in this study is a quantitative approach according to Sugiyono (2017) quantitative approach is a research method based on the philosophy of positivism, used to examine certain populations or samples, data collection using research instruments, quantitative or statistical data analysis with the aim of testing predetermined hypotheses.

In the end, the results of this study explain the causal relationship between the variables through hypothesis testing. This study aims to determine the relationship between three variables, namely the service quality variable (X1) and the price variable (X2) as the independent variable, while the customer satisfaction variable $(\mathrm{Y})$ act as the dependent variable.

Likert scale is used to measure attitudes, opinions, and perceptions of a person or group of people about social phenomena. In research, this social phenomenon has been specifically defined by the researcher, hereinafter referred to as the research variable. With a Likert scale, the variables to be measured are translated into variable indicators. Then the indicator is used as a starting point for compiling instrument items which can be in the form of statements or questions. The Likert scale was obtained based on the results of a questionnaire distributed through Google Form. 


\section{JOURNAL OF MANAGEMENT, ACCOUNTING, GENERAL \\ FINANCE AND INTERNATIONAL ECONOMIC ISSUES \\ (MARGINAL) \\ VOLUME 1 ISSUE 2 (2022)}

Table 1 Likert scale

\begin{tabular}{|l|l|l|l|l|l|l|}
\hline \multirow{2}{*}{ No } & \multirow{2}{*}{ Information } & \multicolumn{4}{|l|}{ Answer } \\
\cline { 3 - 7 } & & SA & A & N & D & SD \\
\hline & & 5 & 4 & 3 & 2 & 1 \\
\hline 1 & Strongly agree & & & & & \\
\hline 2 & Agree & & & & & \\
\hline 3 & Neutral & & & & & \\
\hline 4 & Disagree & & & & & \\
\hline 5 & $\begin{array}{l}\text { Strongly } \\
\text { Disagree }\end{array}$ & & & & & \\
\hline
\end{tabular}

Furthermore, the population in this study are consumers who visit the Grilled Chicken Restaurants of Pak Atok Bakom, Ciawi Bogor. Meanwhile, the sample used was based on the Accidental method, which is a technique for determining the sample based on needs only, members who were met by researchers and were willing to become respondents.

The type of data used in this study is quantitative data, that is, researchers can manage data using rankings, the source of data used in this research is primary data used is data obtained directly from the answers of respondents who have been or are now customers of Grilled Chicken Restaurants of Pak Atok Bakom through an online questionnaire, namely the Google Form. Questionnaires are used to obtain respondent data regarding service quality, price and customer satisfaction with data sources obtained directly from consumers or customers who have been or are now customers of Pak Atok Bakom's Grilled Chicken Restaurant in Ciawi Bogor. Moreover, the data analysis through several test such as Validity test, Reliabiity test, and Hypothesis test.

\section{RESULT AND DISCUSSION}

\subsection{Result Research}

\subsubsection{Convergent Validity Test}

Figure 2 the calculation results of the Smart PLS application can be seen in the loading factor values of the indicators for each variable as follows:

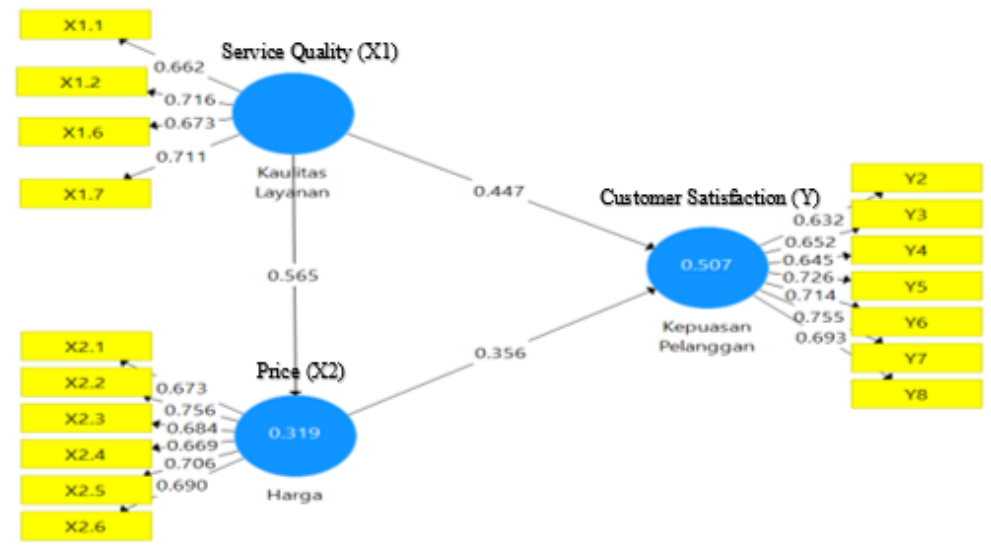

Figure 2 Model Testing 


\section{a. Value of Convergent Validity X1 (Quality of Service):}

In Figure 2 the indicators X1.1, X1.2, X1.6 and X1.7 have a loading factor value above 0,6 , so they have high validity. Meanwhile, indicators of X1.3, X1.4, X1.5 have a loading factor value below 0,6 , which means the validity is low, so it is removed from the model.

Table 2 Value of Convergent Validity X1 (Quality of Service)

\section{b. Value of Convergent Validity X2 (Price)}

\begin{tabular}{|c|c|c|c|}
\hline Variable & Indicator & $\begin{array}{c}\text { Outer } \\
\text { Loading }\end{array}$ & Description \\
\hline \multirow{4}{*}{$\begin{array}{c}\text { Service } \\
\text { Quality }\end{array}$} & $\mathrm{X} 1.1$ & 0.662 & Valid \\
\cline { 2 - 4 } & $\mathrm{X} 1.2$ & 0.716 & Valid \\
\cline { 2 - 4 } & $\mathrm{X} 1.6$ & 0.673 & Valid \\
\hline
\end{tabular}

In Figure 2 none of the indicators has a loading factor value below 0,6 , so that all indicators are still used.

Table 3 Value of Convergent Validity X2 (Price)

\begin{tabular}{|c|c|c|c|}
\hline Variable & Indicator & $\begin{array}{c}\text { Outer } \\
\text { Loading }\end{array}$ & Description \\
\hline \multirow{7}{*}{ Price } & $\mathrm{X} 2.1$ & 0.673 & Valid \\
\cline { 2 - 4 } & $\mathrm{X} 2.2$ & 0.756 & Valid \\
\cline { 2 - 4 } & $\mathrm{X} 2.3$ & 0.684 & Valid \\
\cline { 2 - 4 } & $\mathrm{X} 2.4$ & 0.669 & Valid \\
\cline { 2 - 4 } & $\mathrm{X} 2.5$ & 0.706 & Valid \\
\cline { 2 - 4 } & $\mathrm{X} 2.6$ & 0.690 & Valid \\
\hline
\end{tabular}

\section{c. Convergent Validity Y Value (Customer Satisfaction)}

In the figure 2, the indicators of Y2 to Y8 have a loading factor value above 0,6 so they have high validity. Meanwhile, only Y1 indicators have a factor loading value below 0,6 then the validity is low so they are removed from the model.

Table 4 Value of Convergent Validity Y (Customer Satisfaction)

\begin{tabular}{|c|c|c|c|}
\hline Variable & Indicator & $\begin{array}{c}\text { Outer } \\
\text { Loading }\end{array}$ & Description \\
\hline & $\mathrm{Y} 2$ & 0.632 & Valid \\
\cline { 2 - 4 } & $\mathrm{Y} 3$ & 0.652 & Valid \\
\cline { 2 - 4 } & $\mathrm{Y} 4$ & 0.645 & Valid \\
\cline { 2 - 4 } $\begin{array}{c}\text { Customer } \\
\text { satisfaction }\end{array}$ & $\mathrm{Y} 5$ & 0.726 & Valid \\
\cline { 2 - 4 } & $\mathrm{Y} 6$ & 0.714 & Valid \\
\cline { 2 - 4 } & $\mathrm{Y} 7$ & 0.755 & Valid \\
\cline { 2 - 4 } & $\mathrm{Y} 8$ & 0.693 & Valid \\
\hline
\end{tabular}




\section{JOURNAL OF MANAGEMENT, ACCOUNTING, GENERAL FINANCE AND INTERNATIONAL ECONOMIC ISSUES \\ (MARGINAL) \\ VOLUME 1 ISSUE 2 (2022)}

\section{1) Discriminant Validity Test}

Discriminant validity is used to ensure that each concept of each construct or latent variable is different from other variables. The table below shows the results of the discriminant validity of the research model by looking at the cross-loading value.

a. Analysis of Discriminant Validity Indicator Variable X1 (Quality of Service)

Table 5 Value of Discriminant Validity X1 (Quality of Service)

\begin{tabular}{|c|c|c|c|c|}
\hline Indicator & Price & $\begin{array}{c}\text { Customer } \\
\text { Satisfaction }\end{array}$ & $\begin{array}{c}\text { Service } \\
\text { Quality }\end{array}$ & $\begin{array}{c}\text { Descriptio } \\
\text { n }\end{array}$ \\
\hline X1.1 & 0.339 & 0.431 & 0.662 & Valid \\
\hline X1.2 & 0.436 & 0.469 & 0.716 & Valid \\
\hline X1.6 & 0.378 & 0.515 & 0.673 & Valid \\
\hline X1.7 & 0.402 & 0.360 & 0.711 & Valid \\
\hline
\end{tabular}

From the results of the estimated cross loading in the table above, it shows that the loading value of each indicator item on the construct (X1) is greater than the value of the cross loading. Thus, it can be concluded that all variables already have good discriminant validity, where indicators on turning indicators are better than other block indicators or can be declared valid.

b. Analysis of Discriminant Validity Indicator Variable X2 (Price)

Table 6 Value of Discriminant Validity X2 (Price)

\begin{tabular}{|c|c|c|c|c|}
\hline & Price & $\begin{array}{c}\text { Customer } \\
\text { satisfaction }\end{array}$ & $\begin{array}{c}\text { Service } \\
\text { Quality }\end{array}$ & Information \\
\hline $\mathrm{X} 2.1$ & 0.673 & 0.431 & 0.380 & Valid \\
\hline $\mathrm{X} 2.2$ & 0.756 & 0.469 & 0.438 & Valid \\
\hline $\mathrm{X} 2.3$ & 0.684 & 0.529 & 0.525 & Valid \\
\hline $\mathrm{X} 2.4$ & 0.669 & 0.369 & 0.342 & Valid \\
\hline $\mathrm{X} 2.5$ & 0.706 & 0.369 & 0.375 & Valid \\
\hline $\mathrm{X} 2.6$ & 0.690 & 0.493 & 0.453 & Valid \\
\hline
\end{tabular}

From the results of the estimated cross loading in the table above, it shows that the loading value of each indicator item on the variable (X2) is greater than the value of the cross loading. Thus, it can be concluded that all variables already have good discriminant validity, where indicators on turning indicators are better than other block indicators or can be declared valid. 


\section{c. Analysis of Discriminant Validity Indicator Y Variable (Customer Satisfaction)}

Table 7 Value of Discriminant Validity Y (Customer Satisfaction)

\begin{tabular}{|c|c|c|c|c|}
\hline & Price & $\begin{array}{c}\text { Customer } \\
\text { satisfaction }\end{array}$ & $\begin{array}{c}\text { Service } \\
\text { Quality }\end{array}$ & Description \\
\hline Y2 & 0.380 & 0.632 & 0.352 & Valid \\
\hline Y3 & 0.472 & 0.652 & 0.401 & Valid \\
\hline Y4 & 0.443 & 0.645 & 0.351 & Valid \\
\hline Y5 & 0.399 & 0.726 & 0.505 & Valid \\
\hline Y6 & 0.415 & 0.714 & 0.451 & Valid \\
\hline Y7 & 0.480 & 0.755 & 0.535 & Valid \\
\hline Y8 & 0.346 & 0.693 & 0.503 & Valid \\
\hline
\end{tabular}

From the results of the estimated cross loading in the table above, it shows that the loading value of each indicator item on its construct $(\mathrm{Y})$ is greater than the cross loading value. Thus, it can be concluded that all variables already have good discriminant validity, where the indicators in the indicator block are better than other block indicators or can be declared valid.

\section{2) AverageVariance (AVE) test}

Table 8 AverageVariance Extracted (AVE) Value

\begin{tabular}{|c|c|c|}
\hline Variable & $\begin{array}{c}\text { Average Variance } \\
\text { Extracted (AVE) }\end{array}$ & Description \\
\hline $\begin{array}{c}\text { Service } \\
\text { Quality }\end{array}$ & 0.586 & Reliable \\
\hline Price & 0.577 & Reliable \\
\hline $\begin{array}{c}\text { Customer } \\
\text { satisfaction }\end{array}$ & 0.575 & Reliable \\
\hline
\end{tabular}

From the table above, it is known that the AverageVarianceExtracted (AVE) value has a value below 0,5 . Therefore, there is still a convergentvalidity problem. Thus, it can be concluded that Average Variance Extracted (AVE) has poor reliability because it does not comply with the required minimum value. 


\section{JOURNAL OF MANAGEMENT, ACCOUNTING, GENERAL \\ FINANCE AND INTERNATIONAL ECONOMIC ISSUES \\ (MARGINAL) \\ VOLUME 1 ISSUE 2 (2022)}

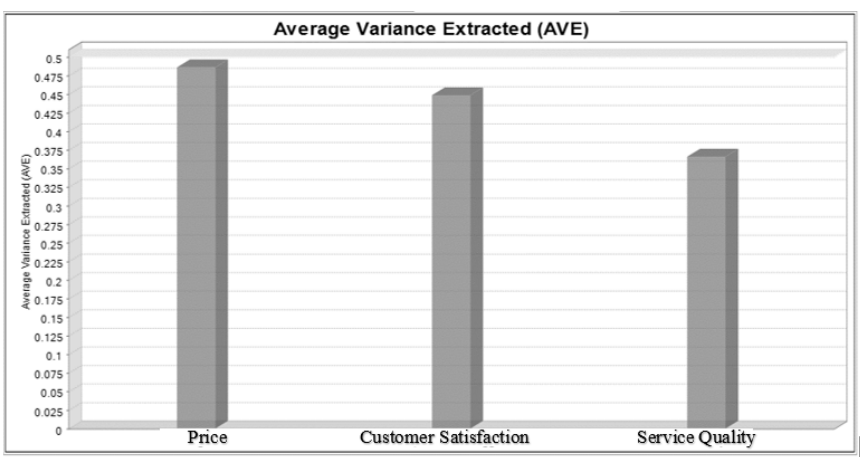

Figure 3 AverageVarianceExtrated (AVE)

\subsubsection{Composite Reliability Test}

The Outer Model can be measured in addition to assessing convergent validity and discriminant validity, which can be done by looking at the reliability of the construct or latent variable which is measured by looking at the compsitereliability value of the indicator block that measures the construct. Outer PLS results for composite reliability and cronbachalpha values can be seen in the following table:

Table 9 Composite Reliability Value

\begin{tabular}{|c|c|c|}
\hline Variable & $\begin{array}{c}\text { Composite } \\
\text { Reliability }\end{array}$ & Description \\
\hline $\begin{array}{c}\text { Service } \\
\text { Quality }\end{array}$ & 0.850 & Reliable \\
\hline Price & 0.785 & Reliable \\
\hline $\begin{array}{c}\text { Customer } \\
\text { satisfaction }\end{array}$ & 0.863 & Reliable \\
\hline
\end{tabular}

The table above shows the compsitereliability values for all constructs that are above the value of 0,7 . Thus, it can be concluded that all variables have good reliability in accordance with the required minimum value limit.

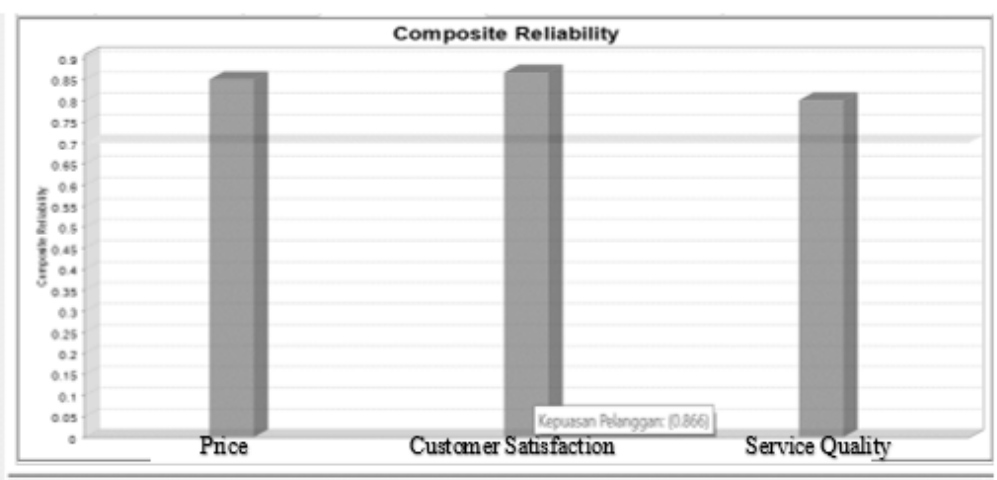

Figure 4 Composite Reliability 


\section{1) Cronbach Alpha test}

The outer model is not only measured by assessing convergent validity and discriminant validity, it can also be done by looking at the reliability of the latent variable which is measured by looking at the cronbachalpha value of the indicator block that measures the variable. The variable is declared reliable if the cronbachalpha value is greater than 0,60 .

Table 10 Cronbach Alpha value

\begin{tabular}{|c|c|c|}
\hline Variable & $\begin{array}{c}\text { Cronbach } \\
\text { Alpha }\end{array}$ & Description \\
\hline $\begin{array}{c}\text { Service } \\
\text { Quality }\end{array}$ & 0.788 & Reliable \\
\hline Price & 0.736 & Reliable \\
\hline $\begin{array}{c}\text { Customer } \\
\text { satisfaction }\end{array}$ & 0.815 & Reliable \\
\hline
\end{tabular}

The table above shows the CronbachAlpha values for all constructs that are above the value of 0,6 . Thus, it can be concluded that all constructs have good reliability in accordance with the required minimum value.

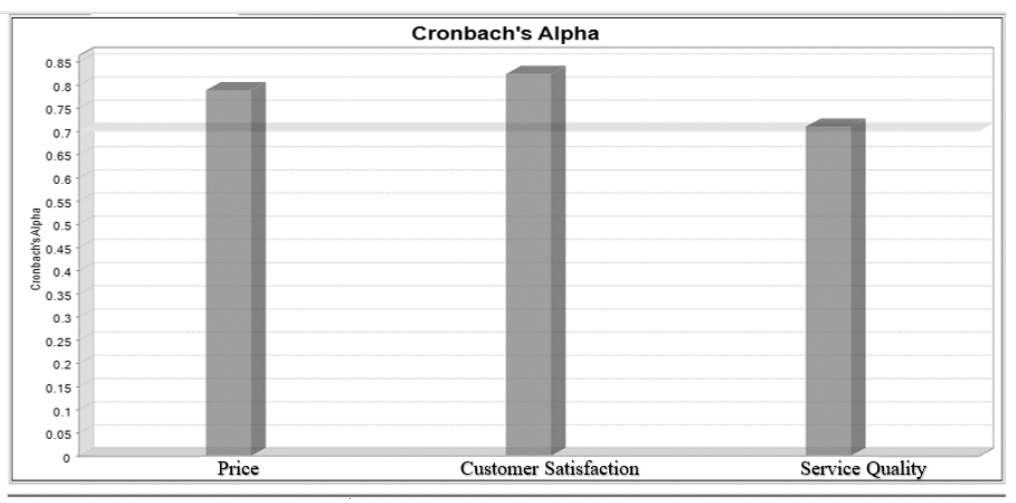

Figure 5 Cronbach Alpha

\subsubsection{Measurement Model of Hypothesis Testing (Bootstrapping)}

In this study, hypothesis testing was carried out based on the results of testing the inner model (Structural Model) which included the output r-square, parameter coefficients and tstatistics. To see whether a hypothesis can be accepted or rejected, among others, by paying attention to the significance value between constructs, $t$-statistics and $p$-values. The hypothesis testing of this research was carried out with the help of the Smart PLS 3.0 software. These values can be seen from bootstrapping. The rule of thumb used in this study is 9-statistic $>1,96$ with a significance level of $p$-value $0,05(5 \%)$ and the fath coefficient is positive. The value of testing this research hypothesis can be shown in the figure as follows: 


\section{JOURNAL OF MANAGEMENT, ACCOUNTING, GENERAL FINANCE AND INTERNATIONAL ECONOMIC ISSUES \\ (MARGINAL) \\ VOLUME 1 ISSUE 2 (2022)}

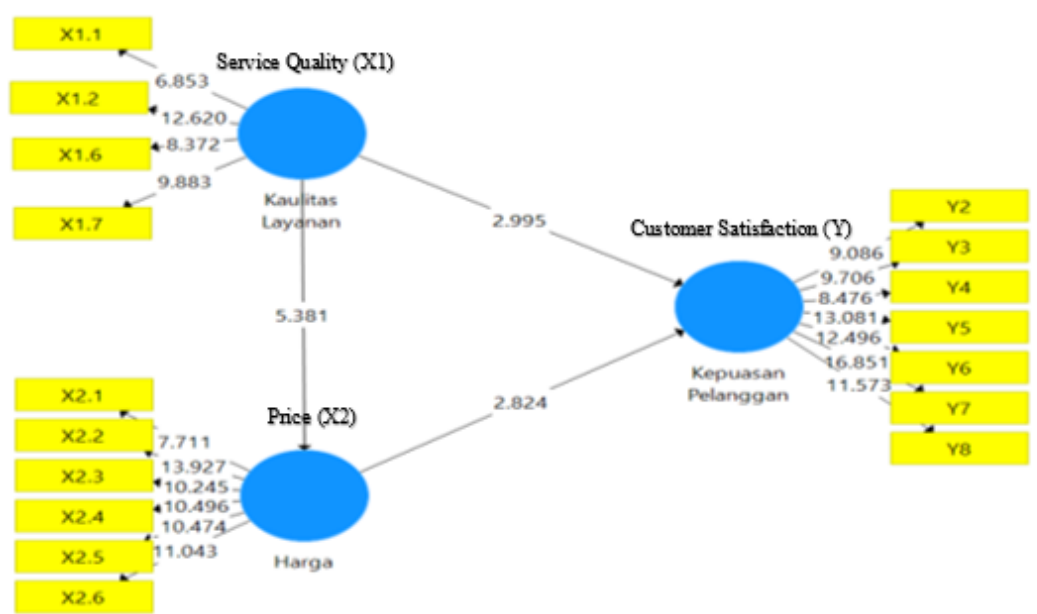

Figure 6 Measurement Model (Bootstrapping)

Direct Effect Hypothesis Testing:

Path coefficient evaluation is used to show how much influence or effect the independent variable has on the dependent variable. The path coefficien value can be seen in the following table:

Table 11 Path Coefficients (Direct Effect)

\begin{tabular}{|c|c|c|c|c|c|c|}
\hline $\begin{array}{c}\text { Path } \\
\text { Coefficients }\end{array}$ & $\begin{array}{c}\text { Original } \\
\text { Sample }\end{array}$ & $\begin{array}{c}\text { Sample } \\
\text { Menu }\end{array}$ & $\begin{array}{c}\text { Standard } \\
\text { Deviation }\end{array}$ & T Statistics & P Values & Description \\
\hline $\begin{array}{c}\text { Service } \\
\text { Quality } \rightarrow \mathrm{Cu} \\
\text { stomer } \\
\text { satisfaction }\end{array}$ & 0.447 & 0.424 & 0.149 & 2,995 & 0.003 & Significant Effect \\
\hline $\begin{array}{c}\text { Price } \rightarrow \text { Cust } \\
\text { omer } \\
\text { satisfaction }\end{array}$ & 0.356 & 0.386 & 0.126 & 2,824 & 0.005 & Significant Effect \\
\hline $\begin{array}{c}\text { Service } \\
\text { quality and } \\
\text { price } \rightarrow \text { Cust } \\
\text { omer } \\
\text { satisfaction }\end{array}$ & 0.565 & 0.583 & 0.105 & 5,381 & 0.000 & Significant Effect \\
\hline
\end{tabular}

\subsection{Discussion}

\subsubsection{The Effect of Service Quality on Customer Satisfaction}

According to the results of this study, it shows that the path coefficient value of the service quality on customer satisfaction of 0,003 and the t-statistic of 2,995. From these results, it is stated that the t-statistic is significant because it is $>1,96$ with $p$ value $<0,05$, so that the hypothesis is accepted. This proves that service quality has a significant effect on customer satisfaction.

\subsubsection{The Effect of Price on Customer Satisfaction}


According to the results of this study, it shows that the path coefficient value of the price on customer satisfaction of 0,005 and the t-statistic of 2,824. From these results, it is stated that the t-statistic is significant because it is $>1,96$ with $p$ value $<0,05$, so that the hypothesis is accepted. This proves that price has a significant effect on customer satisfaction.

\subsubsection{The Effect of Service quality and Price on Customer Satisfaction}

According to the results of this study, it shows that the path coefficient value of service quality and price on customer satisfaction of 0.000 and t-statistics of 5.381. From these results, it is stated that the t-statistic is significant because it is $>1.96$ with $p$ value $<0.05$ so that the hypothesis is accepted. This proves that service quality and price simultaneously has a significant effect on customer satisfaction

\section{CONCLUSION}

To sum up everything that has been stated so far, the following conclusion can be drawn in this study, namely:

1. The results of the path coefficient value of the service quality on customer satisfaction are 0,003 and the $t$-statistic is 2,995 . From these results, it is stated that the $t$-statistic is significant because $>1,96$ with $\mathrm{p}$ value $<0,003$, so that the hypothesis is accepted. This proves that service quality has a significant effect on customer satisfaction.

2. The results of the path coefficient value of the price on customer satisfaction are 0,005 and the $\mathrm{t}$-statistic is 2,824 . From these results, it is stated that the $\mathrm{t}$-statistic is significant because it is $>1,96$ with $p$ value $<0,05$, so that the hypothesis is accepted. This proves that price has a significant effect on customer satisfaction.

3. The results of the path coefficient value of service quality and price on customer satisfaction are 0,000 and the $t$-statistic is 5,381. From these results, it is stated that the $t-$ statistic is significant because $>1,96$ with $p$ value $<0,00$, so that the hypothesis is accepted. This proves that service and price quality simultaneously has a significant effect on customer satisfaction.

\section{Suggestions}

In this study, the researchers suggest several things, namely:

1. For managers of Pak Atok Grilled Chicken Restaurant to further improve their services in order to enhance and maintain customer satisfaction.

2. For researchers, it is better to research on different objects and compare with several other restaurants so that the modeled concept can be improved and provide a broader picture of service quality and price on customer satisfaction. In addition, further research should add other variables that are not yet in this study so that it can improve the understanding of the factors that influence customer satisfaction with the Ayam Bakar restaurant in the Ciawi area of Bogor.

3. Regarding the development of service quality of Pak Atok Grilled Chicken Restaurant, Ciawi Bogor, the company should conduct training related to work and abilities as an effort to improve the provision first.

4. Considering that service quality and price are very important for culinary circles, it should be implemented even better so that it can realize service quality and price for maximum customer satisfaction. 


\section{JOURNAL OF MANAGEMENT, ACCOUNTING, GENERAL FINANCE AND INTERNATIONAL ECONOMIC ISSUES \\ (MARGINAL) \\ VOLUME 1 ISSUE 2 (2022)}

5. For academics, further researchers are expected to examine more sources and references related to educational infrastructure and effectiveness of learning process so that the research results can be better and more complete.

\section{REFERENCES}

Akbar, I. (2020). Pengaruh Kualitas Layanan Dan Harga Terhadap Loyalitas Pelanggan Melalui Mediasi Kepuasan Pelanggan (Studi Pada Warung Bebek Bu Lely). Universitas Muhammadiyah Malang.

Ghozali, I. (2006). Aplikasi analisis multivariate dengan program SPSS. Badan Penerbit Universitas Diponegoro.

Ghozali, I., \& Latan, H. (2015). Partial Least Squares : Konsep, Teknik dan Aplikasi Smart PLS 3.0 untuk Penelitian Empiris. In Universitas Diponegoro.

Kotler, P., \& Keller, K. L. (2012). Marketing Management: Philip Kotler, Kevin Lane Keller. Pearson.

Kristianti, T., \& Rivai, A. R. (2018). Pengaruh Persepsi Harga, Kualitas Produk dan Kualitas Layanan terhadap Kepuasan Pelanggan pada Warunk Upnormal Semarang.

Mutiara, S., Rahmad Solling, H., \& Suardi, A. (2021). Pengaruh Kualitas Layanan Persepsi Harga Dan Cita Rasa Terhadap Kepuasan Konsumen. Jesya (Jurnal Ekonomi \& Ekonomi Syariah), 4(1): 411-.

Praja, A. D. (2018). Pengaruh Kualitas Produk, Persepsi Harga Dan Kualitas Pelayanan Terhadap Kepuasan Konsumen. Journal of Materials Processing Technology 1(1): 18.

Pratama, B. N. (2016). Pengaruh Kualitas Pelayanan, Harga Dan Kualitas Produk Terhadap Kepuasan Konsumen Dan Dampaknya Terhadap Word OfMouth. Skripsi.

Ramadani, E. (2020). Pengaruh Kualitas Produk, Kualitas Layanan Dan Harga Terhadap Kepuasan Pelanggan Pada Warung Makan Bebek Goreng Kang Dono. Skripsi.

Sugiyono. (2017). Metode Penelitian Bisnis: Pendekatan Kuantitatif. Kualitatif, Kombinasi, Dan $R \& D$.

Susanti, N. (2020). Pengaruh kualitas produk, fasilitas dan harga terhadap kepuasan konsumen pada resto betri kecamatan siman kabupaten ponorogo. (Doctoral Dissertation, IAIN Ponorogo).

Thungasal, C. E. (2019). Pengaruh Kualitas Layanan Dan Harga Terhadap Loyalitas Pelanggan Melalui Kepuasan Pelanggan Pada Hotel Kasuari. Agora, 7(1). 
